\title{
Influence of environmental processes on indicators of water quality in the Hanabanilla reservoir, Cuba
}

\author{
Mabel Seisdedo Losa ${ }^{1}$ \& Misael Díaz Asencio ${ }^{1,2}$ \\ ${ }^{1}$ Centro de Estudios Ambientales de Cienfuegos (CEAC). Calle 17 esq. Ave. 46 s/n, Reparto Reina, \\ Cienfuegos, Cuba, CP 55100 \\ ${ }^{2}$ Division of Oceanology. Ensenada Center for Scientific Research and Higher Education. México. Tijuana \\ No.3918, Zona Playitas, CP. 22860, Ensenada, B.C. México
}

*Corresponding author: mabel@gestion.ceac.cu

\begin{abstract}
The objective of this research was to analyze the environmental processes that influence the water quality indicators of the Hanabanilla reservoir, located in one of the highest priority basins in Cuba. Results corresponding to water samples collected at 4 points of this reservoir during 2014-2015 were analyzed. Thermal stratification was evident during the rainy season with the development of the thermocline at depths between 11-13 meters. This process showed influence on the behaviors of $\mathrm{pH}$ and $\mathrm{DO}$, which were related to deterioration signs in other indicators established in the Cuban standards consulted. However, the water quality in terms of trophic status, did not present eutrophic conditions during the analyzed period. The results showed some significant correlations between physical-chemical indicators and significant differences between the two seasons, reflecting the influence of the environmental processes on some water quality indicators. Besides, the cluster analysis allowed the classification of water quality in this reservoir.
\end{abstract}

Key words: correlation, cluster analysis, stratification, basin.

Resumen: Influencia de procesos ambientales en indicadores de la calidad del agua en el embalse Hanabanilla, Cuba. El objetivo de esta investigación fue analizar los procesos ambientales que influyen en los indicadores de calidad del agua del embalse de Hanabanilla, ubicado en una de las cuencas de mayor prioridad en Cuba. Se analizaron los resultados correspondientes a las muestras de agua recolectadas en 4 puntos de este embalse durante el período 2014-2015. La estratificación térmica fue evidente durante la temporada de lluvias con el desarrollo de la termoclina a profundidades entre 11-13 metros. Este proceso mostró influencia en los comportamientos de $\mathrm{pH}$ y OD, los cuales se relacionaron con signos de deterioro en otros indicadores establecidos en las normas cubanas consultadas. Sin embargo, la calidad del agua en términos de estado trófico, no presentó condiciones eutróficas durante el período analizado. Los resultados mostraron algunas correlaciones significativas entre los indicadores físico-químicos y diferencias significativas entre las dos temporadas, lo que refleja la influencia de los procesos ambientales en algunos indicadores de calidad del agua. Además, el análisis de conglomerados permitió clasificar la calidad del agua en este embalse.

Palabras clave: correlación, análisis de conglomerados, estratificación, cuenca.

\section{Introduction}

Reservoirs are aquatic ecosystems of great strategic importance, given the various uses that affect water quality, operating mechanisms and the succession of aquatic communities in rivers and watersheds (Tundisi \& Matsumura 2008). Therefore, it is necessary a proper management of these reservoirs based on comprehensive knowledge.

The most critical problem in terms of Cuba's water resources is not only quantitative, but also 
qualitative, by the contamination of surface waters (Batista, 2002). The dammed water quality depends on the natural and anthropic processes that occur in the reservoir itself and in the watershed. Some studies have concluded that natural processes like weathering, mineral oxidation, buffering processes, climatic conditions, soil erosion, as well as anthropic processes such as agricultural fertilization, industrial and municipal wastewater have considerable effects on water quality (Betancourt \& Suárez 2010, Wang et al. 2013, Mena-Rivera et al. 2017). Hence the importance of having water monitoring programs and knowledge on the geomorphology, the lithology of the watershed, anthropic activities, limnological characteristics of the water resource, etc.

The human consumption of the dammed waters requires a proper resource management and for that, it is important to know the environmental processes with influence on the aquatic system. The increase of nitrogen and phosphorous inputs from anthropogenic activities in the basin can produce changes in the trophic status of the waters. These changes depend on factors like the stratification process, the residence time of the water in the reservoir, among others, and have an impact on its physical-chemical and biological characteristics. Therefore, an appropriate statistical analysis of the data obtained can help to understand the complexity of the environmental processes that remain unexplained by studying isolated variables (Betancourt \& Suárez 2010).

Many applications of Cluster Analysis (CA) for water quality assessments have been reported (Mahbub et al. 2008, Li et al. 2009, Khaledian et al. 2012). CA allows the grouping of water samples on the basis of their similarities in chemical composition. Consequently, it is useful for verifying the spatial variation caused by natural and anthropogenic factors (Wen-Cheng et al. 2011).

Cuba has ten high priority hydrographic basins, based on their characteristics of economic, social and environmental condition (Labaut et al. 2018). The Hanabanilla basin is one of them, and therefore the analysis of the physico-chemical and biological characteristics of the waters in its reservoir is strategy important for the users and managers of this resource. In this sense, this research aims to analyze the environmental processes that influence the water quality indicators of the Hanabanilla reservoir, based on results of environmental monitoring generated during 20142015.

\section{Materials and methods}

Study area: The Hanabanilla reservoir is located in the northern part of the Cienfuegos province, near the border with the Villa Clara province (Figure 1). It was built between 1958 and 1962 through the Hanabanilla and Jibacoa rivers dam. It is one of the deepest reservoirs in Cuba (Table I). Its waters are used for power generation and for human consumption of the cities of Cienfuegos and Santa Clara and other small settlements (Betancourt et al. 2009).

The Hanabanilla basin covers an area of 192 $\mathrm{km}^{2}$ within the Guamuhaya Mountains. This region has a complex geology, with an extensive area of metamorphic and igneous rocks. The soils in the basin are erodible and characterized by a low content of nutrients. This basin has great heights and slopes, in addition to rocks with low degrees of permeability, which favors runoff over infiltration. Annual precipitation in the Hanabanilla basin varies between 1500 and $1900 \mathrm{~mm}$. The period of maximum precipitation is typical from May to October, and the dry period is typically from November to April (Sánchez 2000). The high rainfall values of this area favor the runoff and the increased sedimentation in the Hanabanilla reservoir. According to Díaz-Asencio et al. (2017), this reservoir has an average mass accumulation rate of $1.5 \mathrm{~kg} \mathrm{~m}^{-2}$ year ${ }^{-1}$ and a sedimentary accumulation for surface sediments of $2.2 \mathrm{~cm}_{\text {year }}{ }^{-1}$.

The population in the basin is less than 7000 inhabitants and human activities include coffee plantations and local agricultural production (Labaut et al. 2018).

Sampling and analysis: Four points were selected in Hanabanilla reservoir, one near the outlet of the reservoir (1) and the other three near the main rivers inflow: Hanabanilla river (2), Negro river (3) and Jibacoa river (4).

Four campaigns were carried out during the 2014-2015 period, two corresponding to each season: dry (March/2015 and December/2015) and rainy (October/2014 and June/2015). Water samples were collected with a five-liter Niskin bottle at two depth levels (bottom and surface). The requirements established by APHA (1998) were followed for the preservation of the samples, and then they were transported to the laboratory for analysis.

The following water quality parameters were analyzed: $\mathrm{pH}$, dissolved oxygen (DO), biochemical oxygen demand $\left(\mathrm{BOD}_{5}\right)$, chemical oxygen demand (COD), total nitrogen by Kjeldahl (TNK), nitrate nitrogen $\left(\mathrm{N}-\mathrm{NO}_{3}{ }^{-}\right)$, nitrite nitrogen $\left(\mathrm{N}-\mathrm{NO}_{2}{ }^{-}\right)$, 


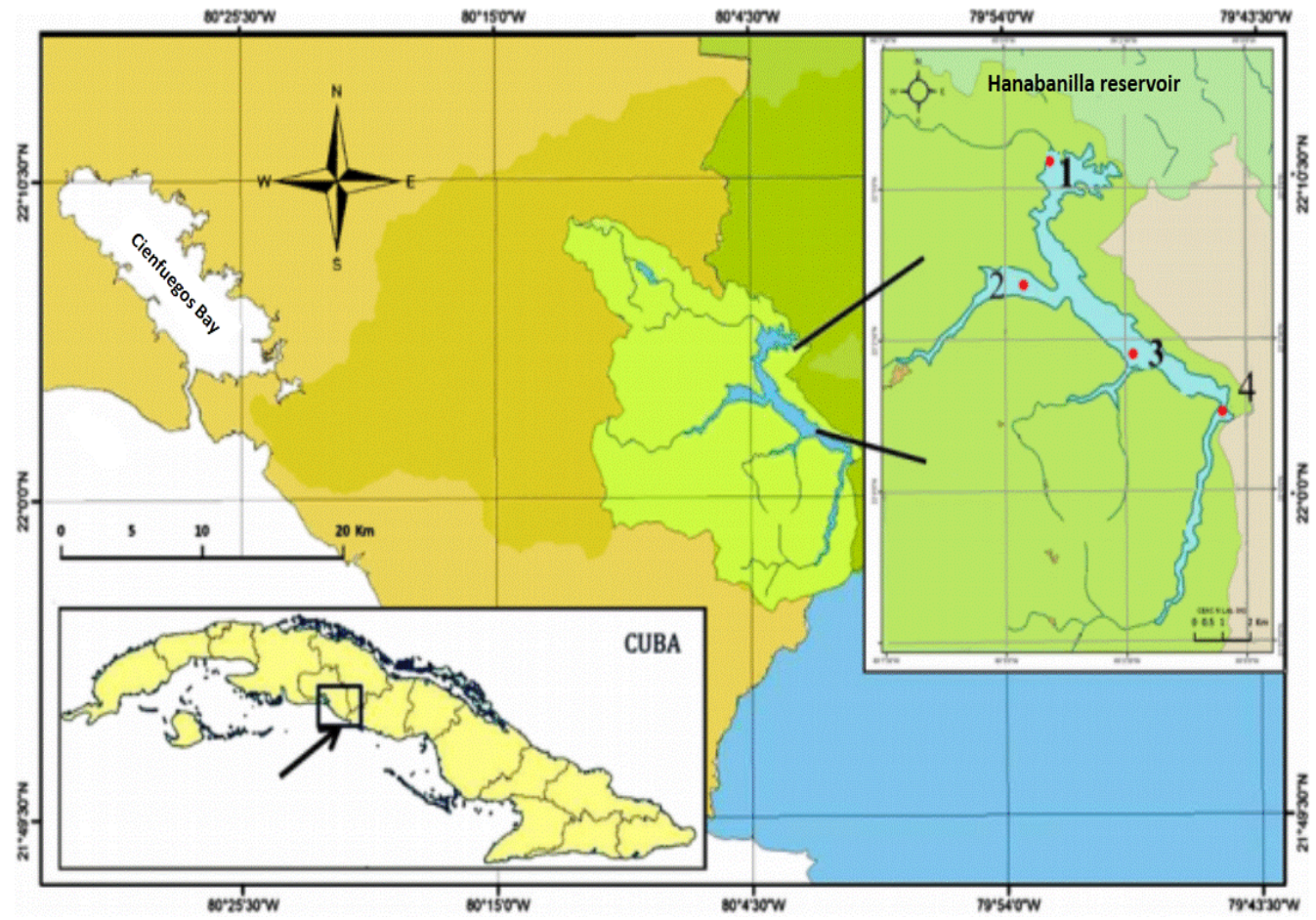

Figure 1. Geographical location of the Hanabanilla basin and the sampling stations in the Hanabanilla reservoir.

Table I. Characteristics of Hanabanilla reservoir

\begin{tabular}{cc}
\hline Characteristic & Value \\
\hline Volume LNW $\left(\mathrm{hm}^{3}\right)$ & 286.0 \\
Volume LMW $\left(\mathrm{hm}^{3}\right)$ & 340.7 \\
Dead Volume $\left(\mathrm{hm}^{3}\right)$ & 14.0 \\
Area $\left(\mathrm{km}^{2}\right)$ & 18.8 \\
Average depth (m) & 15.5 \\
Maximum depth (m) & 43.0 \\
\hline
\end{tabular}

LNW: Level of normal waters, LMW: Level of maximum waters.

ammonium nitrogen $\left(\mathrm{N}-\mathrm{NH}_{4}{ }^{+}\right)$, total phosphorus (TP), orthophosphate phosphorus $\left(\mathrm{P}_{-} \mathrm{PO}_{4}{ }^{3-}\right)$, total hardness (TH), total dissolved solids (TDS), electrical conductivity (EC), temperature (Temp), chlorophyll a (Chla), iron (Fe) and manganese (Mn).

All the analytical essays were carried on in the environmental essays laboratory of the Centro de Estudios Ambientales de Cienfuegos (CEAC). All analytical methodologies used reference analytical protocols based on specifications of APHA (1998).

In the four campaigns, the $\mathrm{pH}, \mathrm{EC}$, Temp and DO were analyzed in situ for the two depth levels. EC and $\mathrm{pH}$ were measured by potentiometric methods, the temperature using the YSI-30 digital probe and the DO was analyzed by the Winkler method. During the campaign carried out in June, a HYDLOLAB probe was used and it allowed the hydrochemical characterization of the entire water column through determinations of temperature, DO and $\mathrm{pH}$.

The TDS concentrations were determined by the gravimetric method and the $\mathrm{TH}$ by titration with EDTA. The concentrations of $\mathrm{N}^{-\mathrm{NH}_{4}}{ }^{+}$were determined by the blue indophenol method, the quantification of $\mathrm{N}^{-} \mathrm{NO}_{2}{ }^{-}$was based on the formation of a highly colored diazo compound of the nitrite ion with the sulfanilamide while $\mathrm{N}-\mathrm{NO}_{3}{ }^{-}$by reduction with hydrazine, all by spectrophometry. The TNK concentrations were determined by the Kjeldahl method, while $\mathrm{P}^{-} \mathrm{PO}_{4}{ }^{3-}$ was determined by the method based on the formation of a complex with ammonium molybdate and antimony tartrate, subsequently reduced with ascorbic acid to obtain a highly blue complex. To quantify the total phosphorus (TP), all forms of phosphorus were converted to orthophosphate, after oxidation of the samples with ammonium persulfate in an acid medium. $\mathrm{BOD}_{5}$ was determined by incubation at $20^{\circ} \mathrm{C}$ for 5 days and for COD the dichromate method with closed reflux was used.

Chlorophyll a (Chla) was analyzed by fluorescence, while the analytical determinations of $\mathrm{Fe}$ and $\mathrm{Mn}$ were performed by Atomic Absorption Spectrophotometry.

Quality control procedures were carried out in order to ensure the quality of the data. In addition, two replicates of the parameters determined in 
laboratory for each sampling site were measured to enhance the reliability of the measured results.

The quality criteria established in Cuban standards for drinking water (ONN 2010) and for water supply source (ONN 2014) were considered for assessing water quality. Besides, the criteria proposed by Vollenweider (1968) were taken into account to identify the limiting nutrient for the development of phytoplankton, as well as OECD criteria (1982) to assess water trophic status.

The RKWard 0.7.1, a graphical interface of statistical language R (Rödiger et al., 2012) was used for data processing. The summary of the information was based on the use of the mean, range and standard deviation (SD), the latter as a measure of dispersion. In addition, Wilcoxon's nonparametric test and the Spearman's Rho correlation were used, as the data do not obey a normal distribution. We used the Wilcoxon test to analyze the significant differences between the results corresponding to two climatic periods and the Spearman's Rho correlation to reveal the relationships among the water quality parameters. A correlation coefficient near -1 or 1 means a strong negative or positive linear relationship between two variables, while close to 0 demonstrates a weak relationship. In this study, the relationships with correlation coefficients greater than 0.5 at the significant level of $\mathrm{p}<0.05$ were chosen for further detailed analysis.

Besides, hierarchical Cluster Analysis (CA) was applied to the standardized data using Ward's method, with Euclidean distance as a measure of similarity. The Ward method applies an analysis of variance approach to assess the distances between clusters to minimize the sum of squares of any two clusters that can be formed at each step. Hierarchical agglomerative clustering is the most common approach, which provides intuitive similarity relationships between any sample and the entire data set, and is typically illustrated by a dendrogram (McKenna 2003). In this case, CA was used to find out the similarities among the sampling stations taking into account the average values of each parameter in the four stations.

\section{Results}

Table II shows the results of the descriptive analyzes carried out for each parameter, in the two depth levels (s-surface and b-bottom) and the two seasons (dry and rainy) considered.

The results of temperature in the entire water column, during the rainy season of 2015, showed the presence of thermal stratification, with a thermocline at depths between 11-13 meters. The observed behaviors for $\mathrm{pH}$ and dissolved oxygen in the water column were similar to that of temperature (Figure 2).

The correlation analysis showed strong and significant correlations between water temperature and indicators such as DO, EC, Fe, Mn and nitrogen forms during the rainy season (Table III). However, during the dry season the temperature did not show significant correlations with the heavy metals analyzed and showed significant correlations with the $\mathrm{pH}, \mathrm{DO}$ and nitrate nitrogen (Table IV).

The spatial analyses of the $\mathrm{DO}$ and $\mathrm{pH}$ showed some sampling stations (1 and 4) with DO concentrations at the deepest level lower than the established minimum limit (EML: $4 \mathrm{mg} / \mathrm{L}$ ) by ONN (2014) and the highest $\mathrm{pH}$ values in the 2014October campaign (Figure $3 \mathrm{~A}, \mathrm{~B}$ ).

Table V shows the analysis of some indicators related to the trophic status of the waters. Their results did not reflect the presence of eutrophic conditions according to the OECD criteria (1982).

Regarding the nitrogen forms, the maximum values of $\mathrm{N}-\mathrm{NH}_{4}{ }^{+}$were obtained at the deepest level in the sampling stations 1 and 4, during the rainy season (Figure $3 \mathrm{C}$ ). This nutrient showed significant correlations with DO, EC, Fe y Mn (Table III). The nitrite and nitrate nitrogen values (Table II), in general, were lower than the established maximum limits in the Cuban standards, which are $0.01 \mathrm{mg} / \mathrm{L}$ and $45 \mathrm{mg} / \mathrm{L}$, respectively. From the TNK and $\mathrm{N}-\mathrm{NH}_{4}{ }^{+}$values (Table II), it was observed that the nitrogen form with the highest presence was the organic one, with maximums in the October 2014 campaign, corresponding to the rainy season (Figure $3 \mathrm{D}$ ). The Wilcoxon test showed significant differences between the results of this indicator in both seasons $(\mathrm{p}<0.05)$.

In relation to TP and $\mathrm{P}_{-} \mathrm{PO}_{4}{ }^{3-}$, concentrations below the quantification limits of the analytical techniques predominated, mainly during the dry season and both indicators showed slightly higher concentrations at the deepest level during the rainy season (Table II).

In this reservoir, the $\mathrm{N} / \mathrm{P}$ ratio calculated from the quantified concentrations of both nutrients yielded values greater than 9 .

The COD values obtained were similar in both seasons (Table II) and concentrations lower than the quantification limit of the analytical technique used $(5 \mathrm{mg} / \mathrm{L})$ predominated. The $\mathrm{BOD}_{5}$ showed a result higher than the established minimum 
Table II. Results of the parameters analyzed in the waters of the Hanabanilla reservoir during 2014-2015

\begin{tabular}{|c|c|c|c|c|c|c|c|}
\hline \multirow[t]{2}{*}{ Parameters } & \multirow[t]{2}{*}{ Unit } & \multicolumn{3}{|c|}{ dry season } & \multicolumn{3}{|c|}{ rainy season } \\
\hline & & Mean & Range & SD & Mean & Range & SD \\
\hline Temp (s) & ${ }^{\circ} \mathrm{C}$ & 25.8 & $25.3-26.8$ & 0.5 & 27.7 & 27.1-29.5 & 0.5 \\
\hline Temp (b) & ${ }^{\circ} \mathrm{C}$ & 24.9 & $22.7-25.6$ & 0.9 & 26.2 & $23.5-27.8$ & 1.4 \\
\hline EC (s) & $\mu \mathrm{S} / \mathrm{cm}$ & 226 & $205-238$ & 12 & 220 & $208-233$ & 10 \\
\hline EC (b) & $\mu \mathrm{S} / \mathrm{cm}$ & 230 & $210-250$ & 14 & 248 & $212-278$ & 27 \\
\hline pH (s) & $\mathrm{pH}$ unit & 8.2 & 7.7-8.4 & 0.3 & 8.5 & 8.1-8.8 & 0.4 \\
\hline $\mathrm{pH}$ (b) & $\mathrm{pH}$ unit & 8.0 & $7.6-8.4$ & 0.3 & 8.2 & $7.4-8.7$ & 0.6 \\
\hline DO (s) & $\mathrm{mg} / \mathrm{L}$ & 7.57 & 4.78-8.91 & 1.31 & 7.86 & $7.25-8.26$ & 0.37 \\
\hline DO (b) & $\mathrm{mg} / \mathrm{L}$ & 6.23 & $2.32-8.48$ & 1.99 & 4.51 & $0.00-6.10$ & 3.50 \\
\hline $\mathrm{BOD}_{5}(\mathrm{~s})$ & $\mathrm{mg} / \mathrm{L}$ & 1.5 & $1.0-2.0$ & 0.3 & 1.3 & $0.6-2.0$ & 0.5 \\
\hline $\mathrm{BOD}_{5}$ (b) & $\mathrm{mg} / \mathrm{L}$ & 1.6 & $0.9-2.6$ & 0.6 & 1.3 & $0.3-2.3$ & 0.7 \\
\hline COD (s) & $\mathrm{mg} / \mathrm{L}$ & 4.4 & $<5.0-5.8$ & 0.9 & 4.3 & $<5.0-6.4$ & 0.9 \\
\hline COD (b) & $\mathrm{mg} / \mathrm{L}$ & 4.6 & $<5.0-6.4$ & 1.0 & 4.2 & $<5.0-5.3$ & 0.5 \\
\hline $\mathrm{N}-\mathrm{NO}_{3}^{-}(\mathrm{s})$ & $\mathrm{mg} / \mathrm{L}$ & 0.025 & $0.002-0.060$ & 0.020 & 0.008 & $0.002-0.013$ & 0.004 \\
\hline $\mathrm{N}-\mathrm{NO}_{3}{ }^{-}(\mathrm{b})$ & $\mathrm{mg} / \mathrm{L}$ & 0.027 & $0.010-0.050$ & 0.016 & 0.015 & $0.002-0.045$ & 0.018 \\
\hline $\mathrm{N}-\mathrm{NO}_{2}^{-}(\mathrm{s})$ & $\mu g / L$ & 1.30 & $0.30-4.00$ & 0.90 & 1.50 & $0.60-3.90$ & 0.80 \\
\hline $\mathrm{N}-\mathrm{NO}_{2}^{-}$(b) & $\mu g / L$ & 3.30 & $0.70-9.00$ & 3.90 & 2.30 & $0.80-8.90$ & 3.10 \\
\hline $\mathrm{N}-\mathrm{NH}_{4}^{+}(\mathrm{s})$ & $\mathrm{mg} / \mathrm{L}$ & 0.216 & $0.010-0.670$ & 0.280 & 0.034 & 0.009-0.093 & 0.040 \\
\hline $\mathrm{N}-\mathrm{NH}_{4}^{+}$(b) & $\mathrm{mg} / \mathrm{L}$ & 0.267 & $0.080-0.690$ & 0.250 & 0.261 & $0.009-0.890$ & 0.320 \\
\hline TNK (s) & $\mathrm{mg} / \mathrm{L}$ & 0.59 & $0.05-1.41$ & 0.48 & 1.60 & $0.03-3.59$ & 1.26 \\
\hline TNK (b) & $\mathrm{mg} / \mathrm{L}$ & 0.53 & $0.09-1.51$ & 0.50 & 1.54 & $0.49-2.81$ & 0.84 \\
\hline $\mathrm{P}-\mathrm{PO}_{4}{ }^{3-}(\mathrm{s})$ & $\mathrm{mg} / \mathrm{L}$ & $<0.004$ & & & 0.005 & $<0.004-0.005$ & 0.001 \\
\hline $\mathrm{P}-\mathrm{PO}_{4}{ }^{3-}$ (b) & $\mathrm{mg} / \mathrm{L}$ & $<0.004$ & & & 0.006 & $<0.004-0.013$ & 0.003 \\
\hline TP (s) & $\mathrm{mg} / \mathrm{L}$ & $<0.009$ & & & 0.011 & $<0.009-0.016$ & 0.003 \\
\hline TP (b) & $\mathrm{mg} / \mathrm{L}$ & $<0.009$ & & & 0.017 & $<0.009-0.049$ & 0.014 \\
\hline TH (s) & $\mathrm{mg} / \mathrm{L}$ & 173 & $150-210$ & 19 & 210 & $144-360$ & 76 \\
\hline TH (b) & $\mathrm{mg} / \mathrm{L}$ & 167 & $146-194$ & 18 & 303 & $144-1000$ & 287 \\
\hline TDS (s) & $\mathrm{mg} / \mathrm{L}$ & 168 & $133-242$ & 37 & 146 & $141-153$ & 5 \\
\hline TDS (b) & $\mathrm{mg} / \mathrm{L}$ & 156 & $122-222$ & 30 & 154 & $144-165$ & 10 \\
\hline Chla (s) & $\mu g / L$ & 1.50 & $0.83-2.37$ & 0.52 & 1.25 & $1.05-1.71$ & 0.21 \\
\hline Chla (b) & $\mu g / L$ & 0.97 & $0.48-1.49$ & 0.41 & 0.95 & $0.05-3.22$ & 1.06 \\
\hline $\mathrm{Fe}(\mathrm{s})$ & $\mathrm{mg} / \mathrm{L}$ & 0.092 & 0.013-0.035 & 0.110 & 0.159 & $0.067-0.052$ & 0.150 \\
\hline Fe (b) & $\mathrm{mg} / \mathrm{L}$ & 0.087 & $0.006-0.228$ & 0.090 & 0.369 & 0.099-0.940 & 0.320 \\
\hline Mn (s) & $\mathrm{mg} / \mathrm{L}$ & 0.031 & $0.012-0.060$ & 0.020 & 0.146 & $0.012-1.078$ & 0.380 \\
\hline Mn (b) & $\mathrm{mg} / \mathrm{L}$ & 0.087 & $0.012-0.220$ & 0.080 & 0.121 & $0.012-0.830$ & 0.290 \\
\hline
\end{tabular}

s: surface, b: bottom 


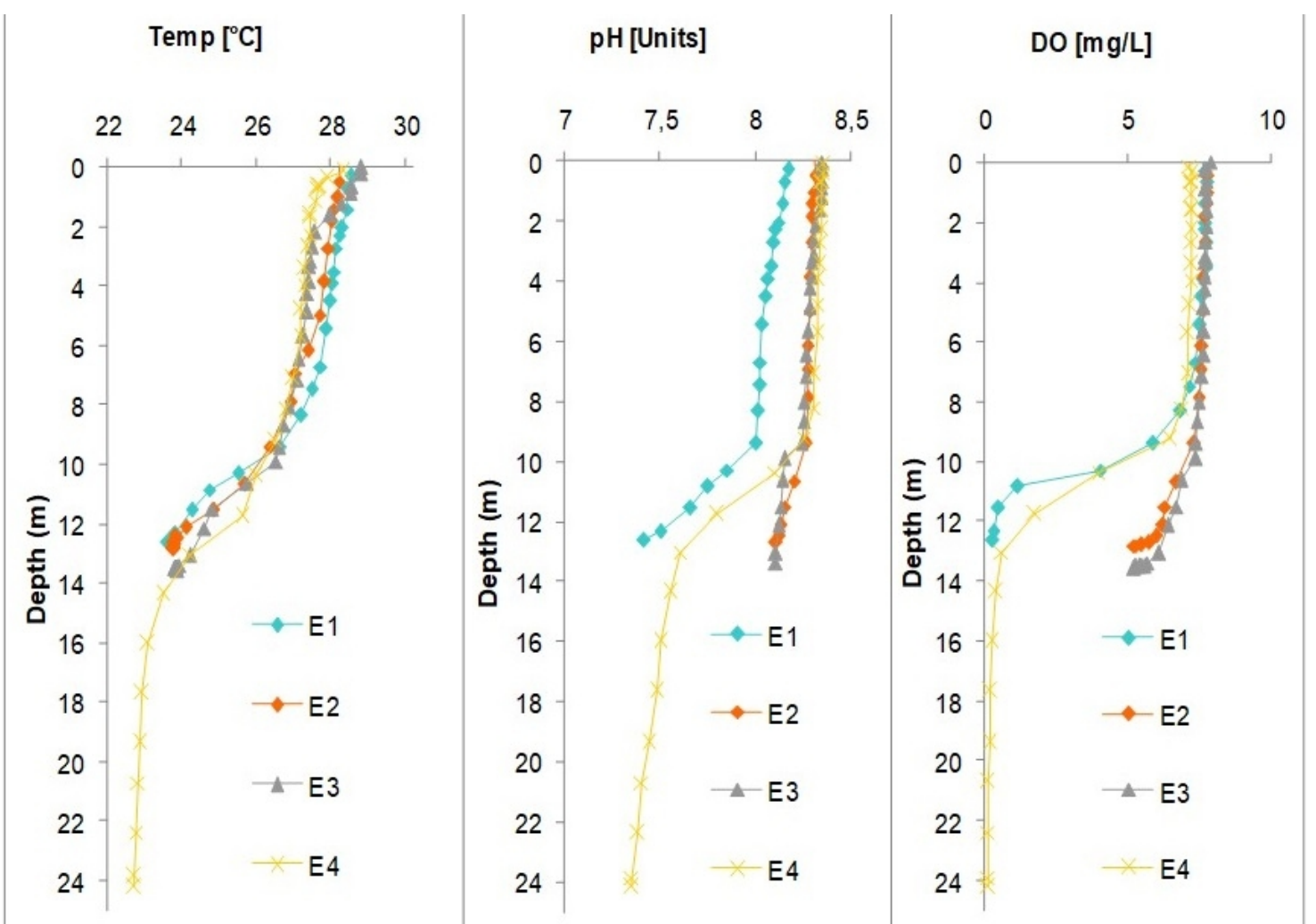

Figure 2. Thermocline representation (temperature vs. depth) and vertical distribution of the pH and DO during the rainy period of 2015 .

limit $(4 \mathrm{mg} / \mathrm{L})$ at the deepest level of the sampling station 4, during one of the rainy season campaigns (Figure 4 A). Similarly, the total hardness showed only a higher concentration than the established maximum limits $(400 \mathrm{mg} / \mathrm{L})$ in the June 2015 campaign, corresponding to the deepest level of sampling station 4 (Figure $4 \mathrm{~B}$ ). This indicator also showed a significant correlation with $\mathrm{pH}$ during the rainy season (Table III).

The range of the values obtained of total dissolved solids was between 122 and $242 \mathrm{mg} / \mathrm{L}$ (Table II) and there was no significant difference between both seasons ( $p>0.05)$.

The range of EC values obtained was between 205 and $278 \mathrm{mg} / \mathrm{L}$. During the rainy season, the maximum value and a greater variation between its results of both depth levels were obtained (Table II). The EC results also showed significant correlations with $\mathrm{DO}, \mathrm{Fe}, \mathrm{Mn}$, and nitrogen forms during the rainy season (Table III) and only with $\mathrm{N}-\mathrm{NH}_{4}{ }^{+}$during dry season (Table IV).

The $\mathrm{Fe}$ and $\mathrm{Mn}$ results showed some concentrations higher than the established maximum limit (EML), mainly in the rainy season (Figure $4 \mathrm{C}$, D). Differences ( $>>0.05$ ) between the results of both seasons for the two metals were obtained.
The cluster analysis produced a dendrogram (Figure 5), grouping two (2 and 3) of the four sampling stations into one cluster while the remaining two stations were separated from the group and between them. Station 4 had the most distance from other stations.

\section{Discussion:}

Thermal stratification is a process that occurs vertically in the water column, dividing it into three layers known as epilimnium, metalimnium and hypolimnium. The water layer on the surface absorbs more heat than the deeper layers; therefore, it becomes less dense than the deeper layers and prevents their mixing. This process depends on the action of the wind, the movements of water masses and their morphometry (Boehrer \& Schultze 2008, Wetzel 2001).

The significant correlations between water temperature and indicators such as DO, Fe and Mn during the rainy season could be related to the thermal stratification. With the increase in temperature, it is expected that the solubility of the DO and therefore its concentration will decrease; however, conditions of anoxia and hypoxia generally occur in the hypolimnium although this layer receives less heat and these conditions influence 
Table III. Spearman correlation matrix corresponding to rainy period $\left(\mathrm{n}=16,{ }^{*} \mathrm{p}<0.01 ; * * \mathrm{p}<0.05\right)$

\begin{tabular}{|c|c|c|c|c|c|c|c|c|c|c|c|c|}
\hline & pH & Temp & EC & DO & BOD & TNK & TH & $\mathbf{F e}$ & Mn & Chla & $\mathbf{N}-\mathrm{NH}_{4}$ & $\mathrm{~N}-\mathrm{NO}_{3}$ \\
\hline pH & 1.000 & -.116 & .029 & .221 & -.244 & $.524 * *$ & $-.620 * *$ & -.066 & .270 & -.312 & .033 & $.615^{* *}$ \\
\hline Temp & & 1.000 & $-.958 * *$ & $.639 *$ & -.055 & $-.511 * *$ & .262 & $-.728 *$ & $-.599 * *$ & .457 & $-.821 *$ & $-.592 * *$ \\
\hline EC & & & 1.000 & $-.600 * *$ & .091 & .374 & -.261 & $.805^{*}$ & $.618^{* *}$ & $-.544 * *$ & $.845^{*}$ & $.531 * *$ \\
\hline DO & & & & 1.000 & -.214 & -.255 & -.229 & $-.585^{* *}$ & -.360 & .204 & $-.764 *$ & -.207 \\
\hline BOD & & & & & 1.000 & -.041 & -.055 & .373 & $.509 * *$ & .343 & .268 & -.123 \\
\hline TNK & & & & & & 1.000 & -.418 & .224 & .333 & -.135 & .444 & $.587 * *$ \\
\hline TH & & & & & & & 1.000 & -.119 & -.207 & .367 & -.163 & $-.525^{*}$ \\
\hline Fe & & & & & & & & 1.000 & $.660^{*}$ & -.318 & $.853^{*}$ & $.504 * *$ \\
\hline Mn & & & & & & & & & 1.000 & .237 & $.609 * *$ & .486 \\
\hline Chla & & & & & & & & & & 1.000 & -.322 & $-.518 * *$ \\
\hline $\mathbf{N}-\mathbf{N H}_{4}$ & & & & & & & & & & & 1.000 & $\begin{array}{c}0.544^{*} \\
*\end{array}$ \\
\hline $\mathrm{N}-\mathrm{NO}_{3}$ & & & & & & & & & & & & 1.000 \\
\hline
\end{tabular}

Table IV. Spearman correlation matrix corresponding to dry period $\left(\mathrm{n}=16,{ }^{*} \mathrm{p}<0.01 ; * * \mathrm{p}<0.05\right)$

\begin{tabular}{|c|c|c|c|c|c|c|c|c|c|c|c|c|}
\hline & pH & Temp & EC & DO & BOD & TNK & TH & $\mathbf{F e}$ & Mn & Chla & N-NH 4 & $\mathbf{N}-\mathrm{NO}_{3}$ \\
\hline pH & 1.000 & $.634 *$ & .279 & $.866^{*}$ & .174 & -.493 & 0.054 & -.396 & $-.625^{*}$ & .436 & $-.626 *$ & $-.671^{*}$ \\
\hline Temp & & 1.000 & -.007 & $.588 * *$ & .118 & -.188 & -.127 & -.053 & -.238 & .157 & -.154 & $-.549 * *$ \\
\hline EC & & & 1.000 & .001 & .106 & -.171 & .202 & -.475 & -.111 & -.165 & $-.526 * *$ & -.447 \\
\hline DO & & & & 1.000 & .065 & -.506 & .216 & -.311 & $-.599 * *$ & $.549 * *$ & $-.500 * *$ & $-.578 * *$ \\
\hline BOD & & & & & 1.000 & 0.334 & .496 & -.354 & .034 & .231 & -.291 & .164 \\
\hline TNK & & & & & & 1.000 & 0.311 & .303 & .133 & .172 & .319 & .268 \\
\hline TH & & & & & & & 1.000 & -.346 & -.210 & $.508 * *$ & -.453 & -.025 \\
\hline $\mathbf{F e}$ & & & & & & & & 1.000 & .451 & -.255 & $.605^{* *}$ & .195 \\
\hline Mn & & & & & & & & & 1.000 & .479 & $.578 * *$ & .467 \\
\hline Chla & & & & & & & & & & 1.000 & -.413 & -.177 \\
\hline $\mathbf{N}-\mathbf{N H}_{4}$ & & & & & & & & & & & 1.000 & $0.556 * *$ \\
\hline $\mathrm{N}-\mathrm{NO}_{3}$ & & & & & & & & & & & & 1.000 \\
\hline
\end{tabular}

some redox processes related to the analyzed metals (Betancourt et al. 2010).

The significant correlation between temperature and $\mathrm{pH}$ during the dry season may be due to a higher consumption of $\mathrm{CO}_{2}$ by phytoplankton in the surface layer that receives more solar radiation and heat. However, in the rainy season other factors not determined in this study (alkalinity, sulfate and chloride) could influence the $\mathrm{pH}$ values considering some results reported by García et al. (2019).
The notable reduction of DO could be related to the morphology of the vessel and not to the trophic status of the water, considering that the analysis of other indicators did not show eutrophic conditions in the waters (Table V), even though massive growths of phytoplankton may appear according to Comas et al. (2017).

The results of $\mathrm{N}-\mathrm{NH}_{4}{ }^{+}$reflected the presence of some deterioration signs in this reservoir taking into account that uncontaminated waters frequently contain concentrations below $0.1 \mathrm{mg} / \mathrm{L}$, according to Betancourt \& Labaut (2013). The increase in its 


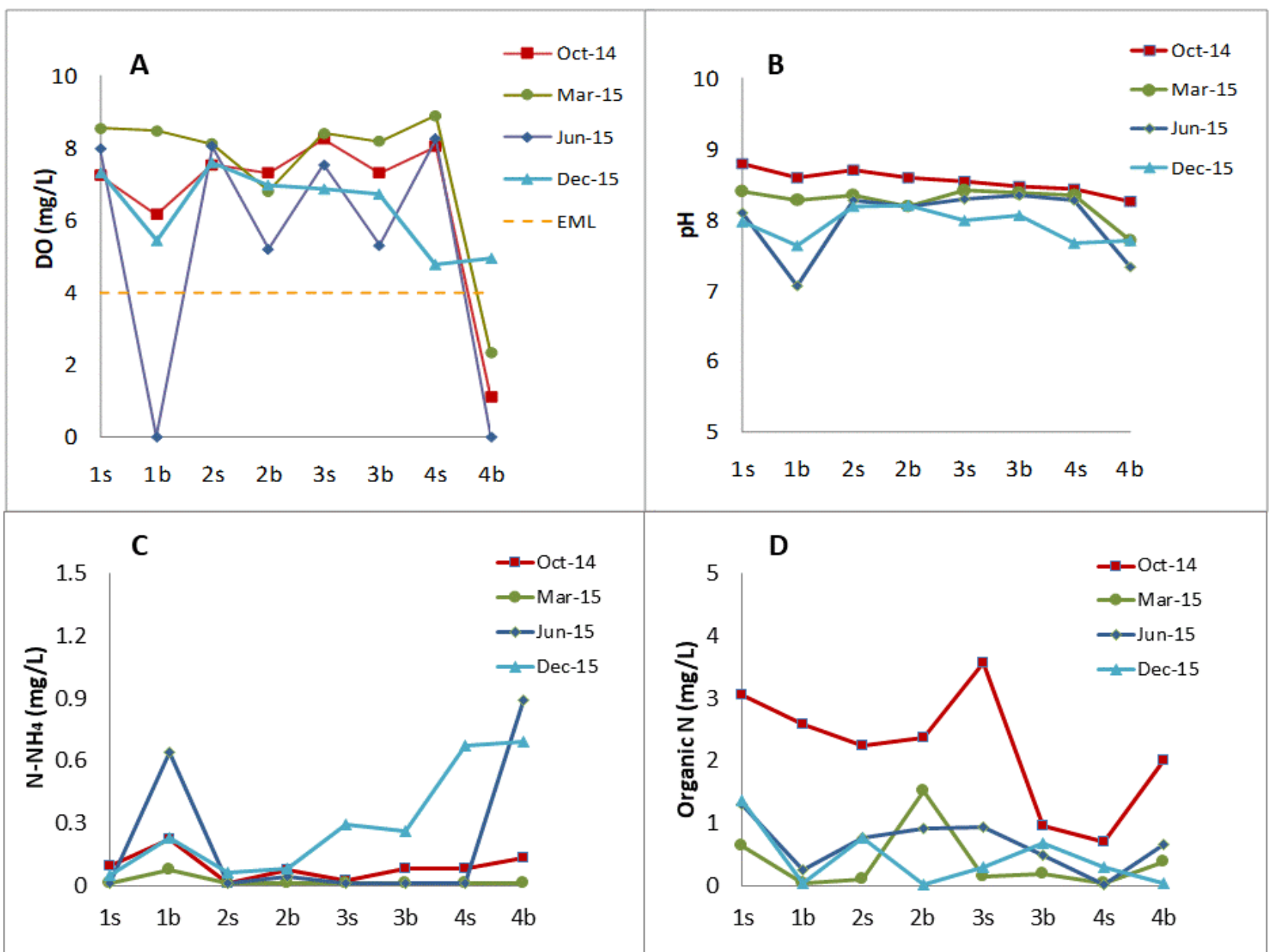

Figure 3. Distribution of DO (A), $\mathrm{pH}(\mathrm{B}), \mathrm{N}-\mathrm{NH}_{4}(\mathrm{C})$ and organic nitrogen (D) in Hanabanilla reservoir vs sampling station and depth level (EML: established minimum limit, b: bottom and s: surface).

Table V. Trophic status assessment of water in Hanabanilla reservoir according to OCDE (1982).

\begin{tabular}{cccc}
\hline Indicator & Chla media $(\boldsymbol{\mu g} / \mathbf{L})$ & Chla max. $(\boldsymbol{\mu g} / \mathbf{L})$ & TP annual $(\boldsymbol{\mu g} / \mathbf{L})$ \\
\hline Range & $0.95-1.5$ & $1.5-3.2$ & $9.8-17$ \\
Assessment & Ultraoligo-Oligotrophic & Meso-Oligotrophic \\
\hline
\end{tabular}

concentrations in the hypolimnium when it becomes anoxic was exposed by Beutel et al. (2008) and justifies obtaining a negative and significant correlation between $\mathrm{N}_{-} \mathrm{NH}_{4}^{+}$and DO during the rainy period (Table III) in which the runoff contribute to a greater incorporation of the nitrogen forms quantified by the Kjeldahl method (Table II).

The low concentrations of $\mathrm{N}-\mathrm{NO}_{2}^{-}$obtained in this study are in correspondence with levels reported in fresh water, which are generally $0.001 \mathrm{mg} / \mathrm{L}$ and rarely reach values higher than $1 \mathrm{mg} / \mathrm{L}$ (Betancourt \& Labaut 2013). This is an unstable nitrogen form in aerated waters, which characterizes the intermediate state in the nitrification and denitrification processes.
Nor did the $\mathrm{N}-\mathrm{NO}_{3}{ }^{-}$values exceed the concentration of $0.1 \mathrm{mg} / \mathrm{L}$ (Table II), that indicates contamination by industrial residues, sewers and leachates from crop areas according to Chapman (1996).

The differences shown between the obtained concentrations of organic nitrogen (Figure 5) in the two sampling campaigns corresponding to the rainy season (October/2014 and June/2015), could be related to the meteorological drought. This event generated notable deficits in the first quarter of the rainy season in 2015, according to a study by Barcia et al. (2019), based on the analysis of the Standardized Precipitation Index (SPI) and it could be link to obtaining greater variability in the TNK 


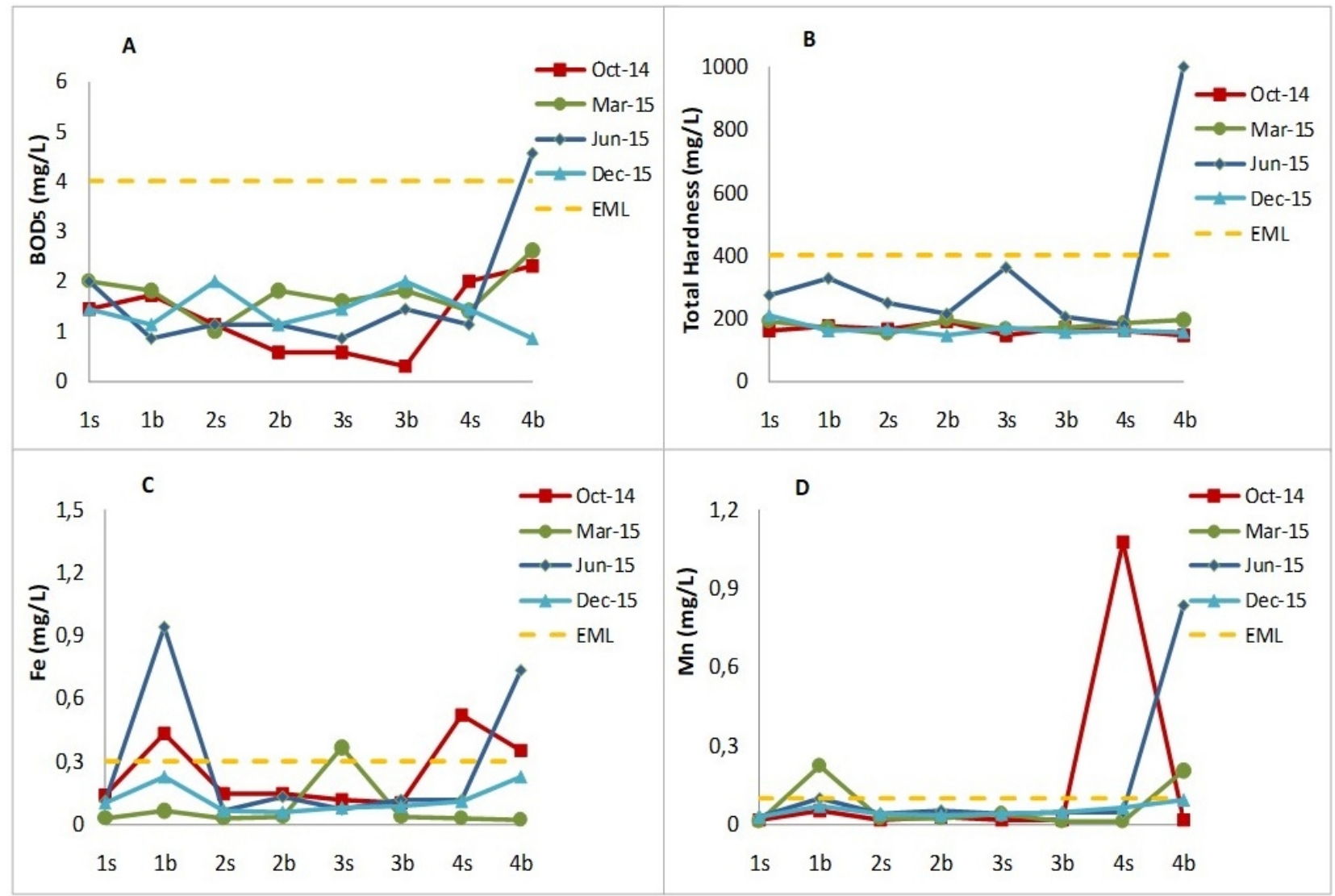

Figure 4. Distribution of $\mathrm{BOD}_{5}(\mathrm{~A})$, total hardness (B), $\mathrm{Fe}(\mathrm{C})$ and $\mathrm{Mn}(\mathrm{D})$ in Hanabanilla reservoir vs sampling station and depth level (EML: established minimum limit, b: bottom and s: surface).

results that corresponded to the rainy season (Table II).

Even though the Cuban standards consulted do not establish criteria for TP and $\mathrm{P}_{-} \mathrm{PO}_{4}{ }^{3-}$, the results obtained in this reservoir did not reflect the presence of contamination, since the concentration of TP in fresh water varies from values less than 5 $\mu \mathrm{g} / \mathrm{L}$ in clean waters up to $200 \mu \mathrm{g} / \mathrm{L}$ in productive waters according to Wetzel (2001). However, the presence of higher concentrations at the deepest level during the rainy season could be due to the release of this species from sediments. The results of a research by Labaut et al. (2018) revealed the influence of the geologic nature of basin on the preferential retention of $\mathrm{P}$ in sediments of the Hanabanilla reservoir.

The distribution patterns of physical and chemical characteristics such as temperature, dissolved oxygen, redox potential and $\mathrm{pH}$ determine the recycling of nutrients, metals and organic matter from sediments in reservoir waters (Betancourt et al. 2009).

The obtaining of N/P ratio values greater than 9 indicates that the limiting nutrient is phosphorus according to the criteria proposed by Vollenweider (1968), which suggests that is necessary to manage the sources of this nutrient in the basin.

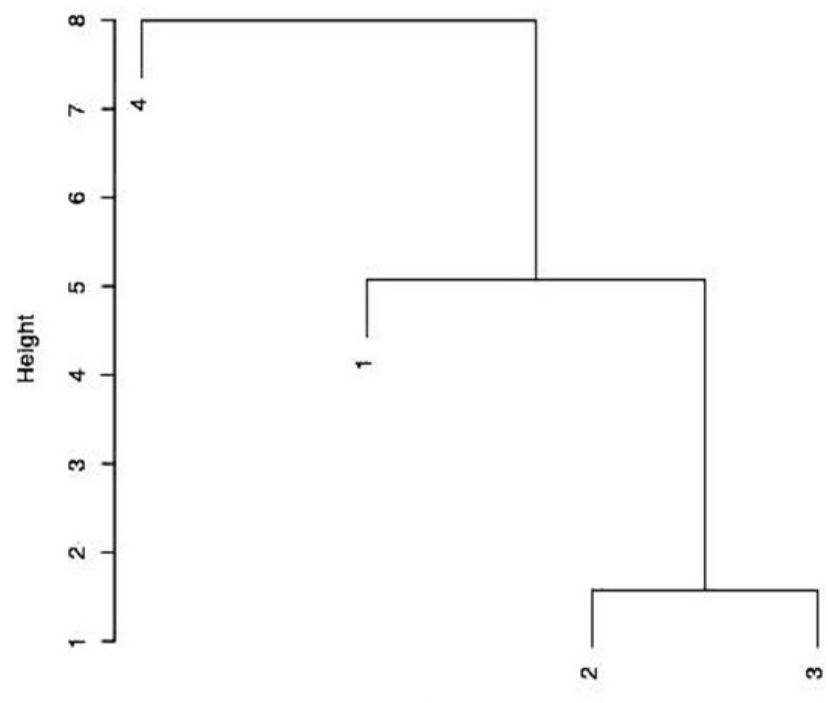

stations

\section{Method=ward; Distance=euclidian}

Figure 5. Dendrogram of cluster analysis for sampling stations (1: Outlet of the reservoir, 2: Hanabanilla river, 3: Negro river and 4: Jibacoa river) according to water quality parameters of Hanabanilla reservoir. 
The chemical oxygen demand (COD) and the biochemical oxygen demand $\left(\mathrm{BOD}_{5}\right)$ reflect the amount of oxygen consumed in the chemical and biological degradation of organic matter, respectively. The $\mathrm{BOD}_{5}$ concentration higher than the established maximum limit obtained in the sampling station 4 (Figure $4 \mathrm{~A}$ ) reflects a risk associated with the deterioration of water quality of this reservoir occurring at the deepest level, during the rainy season.

All the results of TDS were lower than the established maximum limits (1000 mg/L). Even though it could be expected that levels of this indicator increase during the rainy season with the increase of runoff, the non-obtaining of a significant difference between both periods ( $>>0.05$ ), could have been due to the influence of meteorological drought. This phenomenon, although it was notable in the province during the first quarter of the 2015 rainy season, began to occur in 2014 (Barcia et al. 2019).

Total hardness is an indicator related to the levels of Calcium and Magnesium ions. Its high concentration at the deepest point and during one of the sampling campaigns with stratification may be due to the release of these ions from the sediment under anoxic conditions in the hypolimnium, which induce the change in redox potential conditioning the dynamics in the sediment-water interface (Bustamante et al. 2002). In addition, the presence in the basin of minerals rich in $\mathrm{Ca}$ and $\mathrm{Mg}$ such as carbonate rocks and rock leaching as the main source of their contribution, according to Betancourt et al. (2010), could be factors related to total hardness values above $200 \mathrm{mg} / \mathrm{L}$, mainly in the rainy season. The presence of these high concentrations can cause the appearance of scale in distribution systems, depending also on the interaction with other factors, such as $\mathrm{pH}$ and alkalinity (WHO 2004).

Although the EC is not an indicator established in the Cuban standards consulted, it was determined in order to know the amount of dissolved salts in the water. In both seasons, the results were in correspondence with the normal values of this parameter in fresh water, which comprise the range of $100-2000 \mu \mathrm{S} / \mathrm{cm}$, as proposed by Sardiñas et al. (2006). The maximum value and a greater variation between the results of the two depth levels during the rainy season, are associated with a greater dispersion of the DO results at the bottom level during the same season, verified by obtaining a significant correlation between both indicators
(Table III). The lack of oxygen generates in response a variation in the redox potential and the chemical bonds of certain sediment compounds are affected, becoming unstable and promoting their release, which is related to the behavior of ions such as $\mathrm{Mn}^{2+}$ and $\mathrm{Fe}^{2+}$ (Bustamante et al. 2002).

The incorporation of these ions into water contributes to the increase of EC values during the rainy season, which justifies the significant correlation obtained between EC and the two metals (Fe and $\mathrm{Mn}$ ). The increase in the deterioration signs linked to the high concentrations of both metals in that season influenced the obtaining of significant differences $(p<0.05)$ between the results of both seasons.

The distinction obtained between the stations from CA (Figure 5) seems to be related to the deterioration degree in water quality, similar to what was identified in a study by Fataei et al. (2011). The two stations (2 and 3) included in the formed cluster correspond to the areas with the best water quality, in the middle of the reservoir. This group is followed by station 1 at the outlet of the reservoir, with an intermediate water quality as it shows some deterioration signs related to the concentrations of $\mathrm{DO}$ and the metals analyzed. As station 4 is the most distant from the other stations, it indicates the worst water quality, corresponding to a greater frequency of deterioration signs, which were previously analyzed.

In stations 1, 2 and 3 the stratification occurs very near to the bottom, different from station 4 , whose depth is much greater $(25 \mathrm{~m})$. This factor related to the morphology of the reservoir, along with the distance between the latter and the outlet, influences that the water residence time in this area is much longer than in the rest of the reservoir and consequently there are almost anoxic conditions in the deepest layer of water (15 m high) during the rainy season.

\section{Conclusions:}

- During the rainy season, the thermal stratification occurred in the reservoir, with the development of the thermocline at depths between 11-13 meters. This process showed an influence on the behavior of indicators such as $\mathrm{pH}$ and $\mathrm{DO}$, which favored the presence of higher concentrations of some nutrients and metals.

The performed statistical analyzes allowed us to identify some relationships between physical-chemical indicators and significant 
differences between the two seasons, reflecting the influence of the environmental processes on some water quality indicators. Besides, the results showed that the CA was useful for the classification of water quality in this reservoir.

- $\quad$ Some deterioration signs of water quality were identified mainly in the rainy season and at the deepest level. However, in terms of trophic status, non-eutrophic conditions were obtained during the analyzed period.

\section{Acknowledgements}

The authors would like to thank the technicians and specialist from the Environmental Essay Laboratory of the Centro de Estudios Ambientales de Cienfuegos for carrying out the sampling and analytical essays, as well as the support received for the development of this research by the RLA /7/019 and GEF-IWEco projects.

\section{References}

APHA. 1998. Standard Methods for the Examination of Water and Wastewater. American Public Health Association, Edición 20th. Washington.

Batista, J. L. 2002. Utilización actual de los recursos hídricos y calidad ambiental. Mapping, 76: 88-94.

Betancourt, C., Suárez, R. \& Toledo, L. 2009. Ciclo anual del nitrógeno y el fósforo en el embalse Paso Bonito, Cienfuegos, Cuba. Limnetica, 28: 79-90.

Betancourt, C., Jorge, F., Suárez, R., Beutel, M. \& Gebremariam, S. 2010. Manganese sources and cycling in a tropical eutrophic water supply reservoir, Paso Bonito Reservoir, Cuba. Lake and Reservoir Management, 26: 217-226.

Betancourt, C.\& Suárez, R. 2010. Influencia de procesos autóctonos y alóctonos sobre las características físicoquímicas del embalse Paso Bonito, Cienfuegos, Cuba. Revista Internacional Contaminación Ambiental, 26 (4): 257-267.

Betancourt, C.\& Labaut, Y. 2013. La calidad físicoquímica del agua en embalses, principales variables a considerar.

Agroecosistemas, 1 (1): 78-103.

Beutel, M. W., Leonard, T. M., Dent, S. R. \& Moore, B. C. 2008. Effects of aerobic and anaerobic conditions on $\mathrm{P}, \mathrm{N}, \mathrm{Fe}, \mathrm{Mn}$ and $\mathrm{Hg}$ accumulation in waters overlaying profundal sediments of an oligo-mesotrophic lake. Water Resources, 42:1953-1962.

Boehrer, B. \& Schultze, M. 2008. Stratification of lakes. Reviews of Geophysics, 4, RG2005: 127. doi:2010.1029/2006RG000210.

Bustamante, M.A., Morillo, S., Rodríguez, M.I., Granero, M., Ruiz, M., Freyer, I., Busso, F., Bonfanti, E. \& Girbal, A. 2002. Estudios para la evaluación de la eutroficación del embalse San Roque mediante la observación, medición y aplicación de herramientas numéricas. Seminario Taller Calidad de Agua en los embalses de Córdoba.

Chapman, D. 1996. Water Quality Assessments. A Guide to Use of Biota, Sedimentsand Water in Environmental Monitoring. Second Edition. Chapman y Hall, London. 651 p.

Comas, A. A., Labaut, Y. \& Peraza, R. 2017. Ocurrencia de Limnoraphis robusta (Parakutty) Komárek et al. (Oscillatoriales, Cyanobacteria) en el embalse Hanabanilla (Cuba Central). Anales de Biología, 39: 1-6.

Díaz-Asencio, M., Corcho-Alvarado, J.A., CartasAguila, H., Pulido-Caraballé, A., Betancourt, C., Smoak, J.M., Alvarez-Padilla, E., LabautBetancourt, Y., Alonso-Hernández, C., Seisdedo-Losa, M. 2017. ${ }^{210} \mathrm{~Pb}$ and ${ }^{137} \mathrm{Cs}$ as tracers of recent sedimentary processes in two water reservoirs in Cuba. Journal of Environmental Radioactivity 177, 290-304.

Fataei, E., Monavari, S. M., Hasani, A. H., Mirbagheri, S. A \& Karbasi, A. 2011. Surface water quality assessment using multivariate statistical techniques: a case study of the Gharasou River Basin, Iran. Environmental Sciences, 8 (4): 137-146.

García, S. L, Arguello, A., Parra, R. \& Pincay, M. 2019. Factores que influyen en el $\mathrm{pH}$ del agua mediante la aplicación de modelos de regresión lineal. INNOVA Research Journal, 4 (2): 59-71.

Khaledian, Y., Ebrahimi, S. \& Bag Mohamadi, H. 2012. Effects of urbanization and changes land use on water geochemical properties. A case study: Gharaso River in Golestan Province, North of Iran. Terrestrial \& Aquatic Environmental Toxicology, 6(2):77-83

Labaut, Y., Betancourt, C. R., Díaz-Asencio, M. \& Beutel, M. 2018. Influence of dominant environmental processes in the tropical Cuban basin Hanabanilla and reservoir on sediment composition. Limnetica, 37(2): 297-309. 
Li, S., Liu, W., Gu, S., Cheng, X., Xu, Z. \& Zhang, Q. 2009. Spatial-temporal dynamics of nutrients in the upper Han River basin, China. Journal of Hazardous Materials, 162:13401346

Lin, J.G. \& Chen, S.Y. 1998. The relationship between adsorption of heavy metal and organic matter in river sediments. Environment International, 24 (3): 345-352.

Mahbub, H., Syed Munaf, A. \& Walid, A. 2008. Cluster analysis and quality assessment of logged water at an irrigation project, eastern Saudi Arabia. Journal of Environmental Management, 86(1): 297-307

McKenna, J.E. 2003. An enhanced cluster analysis program with bootstrap significance testing for ecological community analysis. Environmental Modelling \& Software, 18 (3): 205-220.

OCDE (Organización para la Cooperación y el Desarrollo Económico) 1982. The OCDE List of Social Indicators, Paris.

ONN 2014. NC-1021:2014. Higiene Comunal. Fuentes de abastecimiento de agua. Calidad y protección Sanitaria. Oficina Nacional de Normalización, Cuba.

ONN 2010. NC-827:2010. Agua potable Requisitos sanitarios. Oficina Nacional de Normalización, Cuba.

Rödiger, S., Friedrichsmeier, T., Kapat, P. \& Michalke. M. 2012. RKWard: A comprehensive graphical user interface and integrated development environment for statistical analysis with R. Journal of Statistical Software, 49(9):1-34.

Sánchez, R. 2000. Características del agua del embalse Hanabanilla. Informe técnicodel Departamento Provincial Recursos Hidráulicos en Villa Clara. 18 p.
Sardiñas, S., Chiroles, S., Fernández, M., Hernández, Y. \& Pérez, A. 2006. Evaluación físico-química y microbiológica del agua de la presa El Cacao (Cotorro, Cuba). Higiene y Sanidad Ambiental, 6: 202-206.

Tundisi, J. G. \& Matsumura-Tundisi, T. 2008. Limnologia. São Paulo: Oficina de Textos.

Vollenweider, R.A. 1968. Scientific fundamentals of lake and stream eutrophication, with particularreference to phosphorus and nitrogen as eutro-phication factors. Technical Report DAS/DSI/68.27. OECD. Paris, Francia. 274 p.

Wetzel, R. G. 2001. Limnology. Lake and River Ecosystems, $3^{\text {rd }}$ edition. Academic Press, San Diego. 1006 p.

WORLD HEALTH ORGANIZATION (WHO). 2004 Guidelines for drinking-water quality. Recommendations, 1 (2nd ed.). Geneva.

Wang Y., Wang P., Bai Y., Tian Z., Li J., Shao X., Mustavich L.F. \& Li B.-L. 2013. Assessment of surface water quality via multivariate statistical techniques: A case study of the Songhua River Harbin region, China. Journal of Hydro-Environment Research, 7:30-40. doi: 10.1016/j.jher.2012.10.003.

Mena-Rivera, L., Salgado-Silva, V., BenavidesBenavides, C., Coto-Campo,s J. \& Swinscoe, T. 2017. Spatial and Seasonal Surface Water Quality Assessment in a Tropical Urban Catchment: Burío River, Costa Rica. Water, 9: 558. doi: 10.3390/w9080558.

Wen-Cheng, L., Hwa-Lung, Y. \& Chung-En, C. 2011. Assessment of water quality in a subtropical alpine lake using multivariate statistical techniques and geostatistical mapping: A case study. International Journal of Environmental Research and Public Health, 8: 1126-1140.

Received: April 2021

Accepted: August 2021

Published: November 2021 